\title{
The influence of risk management to credit lending
}

\author{
Ewith Dade Agustin ${ }^{1 *}$, Bunga Indah Bayunitri ${ }^{2}$ \\ Widyatama University, West Java, Indonesia ${ }^{1,}$ \\ Widyatama University, West Java, Indonesia ${ }^{2}$ \\ $\underline{\text { Ewith.agustin@widyatama.ac.id }}^{1 *}$, Bunga.indah@widyatama.ac.id ${ }^{2}$
}

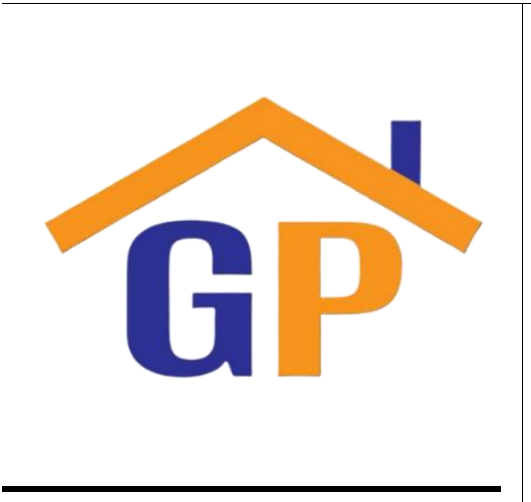

Article History

Received on 4 June 2020

1st Revision on 1 July 2020

$2^{\text {nd }}$ Revision on 16 July 2020

$3^{\text {rd }}$ Revision on 21 July 2020

Accepted on 22 July 2020

\begin{abstract}
Purpose: The purpose of this study was to determine whether risk management influences the provision of credit to PT. BPR Supra Antapersada Bandung. The factors tested in this study were risk management as the independent variable, while credit as the dependent variable.
\end{abstract}

Research Methodology: The method of analysis used is the explanatory method, while the number of samples in this study amounted to 37 employees of PT. BPR Supra Antapersada Bandung. In this study, the analytical method used was a partial (ttest) significance of $5 \%$. The program used to analyze the data was the Version 21.00 of Social Science Statistical Package (SPSS).

Results: The research results partially and simultaneously indicate that risk management affects lending to PT. BPR Supra Antapersada Bandung at $68.1 \%$.

Limitations: Limitation of the problem is the provision of credit to BPR Supra Antapersada in Bandung.

Contribution: This study can be useful for the banking credit sector, and for future researchers.

Keywords: Credit lending, Risk management, PT. BPR Supra Antapersada

How to cite: Agustin, E. D., \& Bayunitri, B. I. (2020). The influence of risk management to credit lending. International Journal of Financial, Accounting, and Management, 2(1), 65-77.

\section{Introduction}

Banking provides the opportunity for the public to participate in the development by organizing fundraising through businesses run by banks, such as savings, deposits, current accounts and credit. The type of banks according to Law No.10 of 1998 includes two classifications namely Commercial Banks and Rural Credit Banks (BPR). BPR is a bank that carries out business activities on a regular basis or based on Sharia rules but simply do not include payment traffic services (Gischa, 2020). Credit activity is the process of forming bank assets so that credit is a bank asset that has risks because these assets are controlled by outsiders (debtors). Banks must be able to manage these assets so that the risk that lies in the assets can contribute to a large income for the bank not to the contrary occur, namely a large loss for the bank. Bank lending certainly has a risk, namely credit risk. Credit risk especially for banks, is that credit becomes bad in the sense that the bank is no longer, or irregular in receiving interest and installments on credit repayments, this, of course, will harm the bank because in addition to the bank not getting interest income, the bank also loses (Suhardi, 2006).

Non-performing loans or bad loans often occur in Indonesian banks, one of which is Bank Perkreditan Rakyat or BPR. The business of BPR includes efforts to collect and distribute funds with the aim of getting profit. Director of Pefindo Credit Bureau Yohanes Arts Abimanyu said one of the causes was bad loans from external factors such as the occurrence of a weakening global economy that also had an impact on the country. "Externally, such a result (economic downturn) results in debtors being 
unable or late in paying. But internally it needs to be seen that the ability or behavior of each debtor also needs to be seen. However external factors still affect the ability to pay," said Yohanes at the Indonesia Stock Exchange Building, Jakarta, Monday (11/11/2019) (Wareza, 2019).

Otoritas Jasa Keuangan (OJK) notes that the BPR Non Performing Loan ratio has exceeded the maximum limit set by Bank Indonesia, that it cannot exceed 5\%. NPLs at the Rural Credit Bank due to external factors such as the weakening of the global economy that also occurred in countries that require debtors to become unable or increase bad loans also increased. Special supervision and attention is needed for OJK to increase the increase in NPLs with the aim of not requiring expansion. Bank Perkreditan Rakyat must increase efforts to prevent and prevent reliable BPR NPLs below five percent (Sari, 2012). Problems faced by banking institutions must be overcome in order to reduce the high level of risk, in this case the bank must improve adequate risk management for lending to reduce bad credit. One method used is to examine the procedure for granting credit established by banks in order to reduce or reduce the level of risk that will be accepted by the bank. Credit risk are risks due to the failure of debtors and / or other parties in fulfilling obligations to BPR (OJK, 2015).

The presence of risk management at the bank will enable banks to apply the precautionary principle optimally so that the procedure for granting credit to customers does not produce bad loans. The responsibility of risk management will involve all resources owned by the bank so that risk management can be one of the supporting procedures for granting credit to BPR in achieving its objectives. Risk management has a very important role in lending procedures to overcome the impact of bad loans which will affect bank profits. The use of risk management processes is very important because it will further enhance our perspective and generality if we carry out active activities and other work units including companies / organizations (Bura \& Kadero, 2013). Therefore the authors are interested in convincing more about the effects of risk management on loans.

\section{Literature review \& hypothesis development}

\subsection{Risk management}

Risk is a danger, the consequences that can occur due to an ongoing process or events that will come. Risk can be interpreted as a state of uncertainty, where if there is an unwanted situation that can cause a loss. In POJK No. 13 / POJK.03 / 2015 states risk management is a collection of methodologies and procedures used for defining, assessing, tracking, and managing risk resulting from all BPR operations (Sugiyanto \& Rahayu, 2018). Risk management in banking is the logical production and execution of a strategy to mitigate future losses (Tursoy \& Turgut, 2018). Suharto, (2015) said credit risk arises because the performance of one or more debtors is bad, this debtor's poor performance can be in the form of the inability of the debtor to fulfill part or all of the contents of the credit agreement that was previously agreed. Risk management is generally regarded as a way to reduce the uncertainty and the impact of uncertainty, thus increasing the chance of the success of the project (Irfandhi, 2016).

\subsection{Credit lending}

In latin kredit is called "credere" which means to believe. That is, the lender believes in the recipient of the loan, that the loan will be returned according to the agreement. As for the recipient of the kredit means receiving trust, so it has an obligation to repay the loan in accordance with the time period (Kasmir, 2015). The loan is based on the loan agreements between banks and other parties requiring a refund of the borrower after a certain period of time, with an interest, following the law of the Republic of Indonesia Number 10 of 1998 (Wikipedia, 2019).

Principles of crediting according to Kasmir, (2014) are:

1. Personality

2. Capacity

3. Capital

4. Condition of Economy

5. Collateral

\subsection{Hypothesis development}

Provision of credit in accordance with procedures by the bank can minimize the occurrence of bad credit. The usual criteria for assessment are common and must be done by banks to get customers 
who are truly eligible for credit with the 5C analysis. Principle 5C consists of Character, Capacity, Capital, Collateral and Condition of economy(Kasmir, 2014). The application of risk management to banks in Indonesia provides many benefits and advantages, because it will significantly help to avoid losses due to various risks that befall. The application of risk management is very important given the huge implications for Indonesian banks. The loss that is often experienced by banks is bad credit (Sari, 2012). The researcher designed a chart of thought frameworks as the following line of thought:

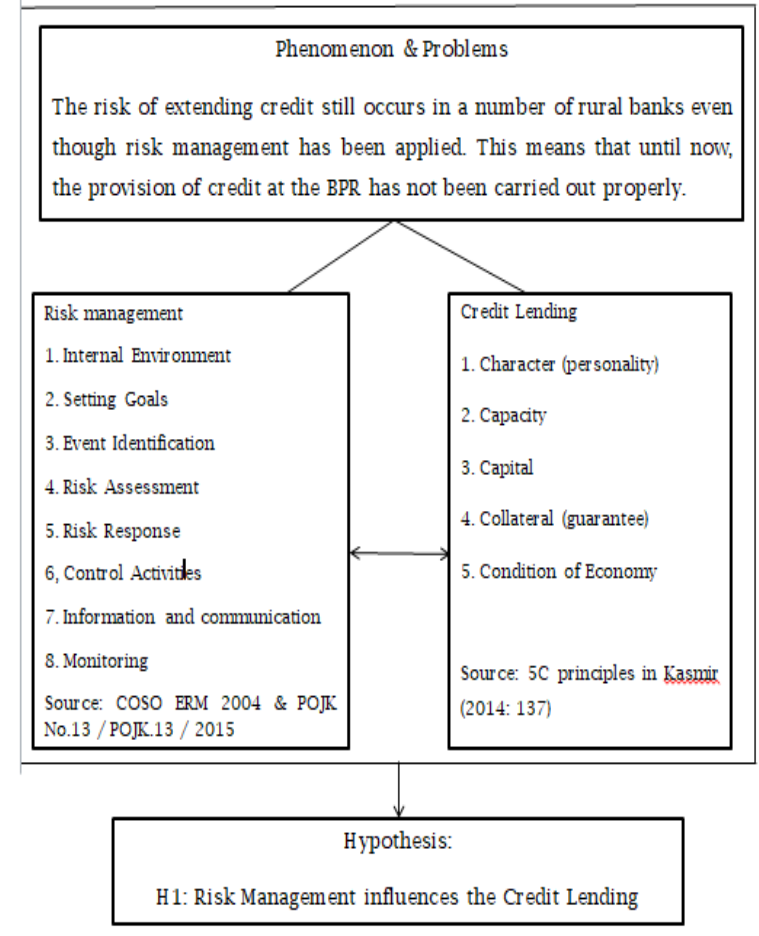

Figure 1: Theoretical Framework

Based on the explanation of the framework of thought, the research can also be described with the following research paradigm:

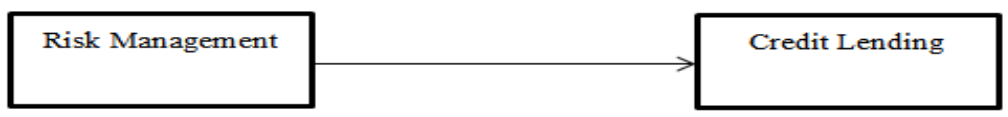

Figure 2

\section{Research paradigm}

Hypothesis can be defined as a logically estimated connection between two variables expressed in query form that can be tested. Based on the explanation of the framework of thought, the hypotheses to be tested in this study are:

H1: Risk Management influences the Giving Credits

\section{Research methodology}

\subsection{Types of research}

Source of data taken in the study is primary data, directly derived from data sources specifically collected and directly related to the problem under study. Primary data collection was done by using a questionnaire. A number of statements addressed to respondents and then respondents were asked to answer all statements in accordance with their opinions.

\subsection{Population and research sample}


A collection of similiar individuals who are in a certain area and at a certain time (Wikipedia, 2020). The population in this study are:

Table 1. Population Table:

\begin{tabular}{|ll|}
\multicolumn{1}{|c|}{ Division } & Number of people \\
\hline Marketing & 5 people \\
\hline Sales & 6 people \\
\hline Credit Analyst & 5 people \\
\hline Collector & 6 people \\
\hline Account Officer & 4 people \\
\hline AdministrasiKredit & 3 people \\
\hline Teller & 3 people \\
\hline Customer service & 2 people \\
\hline Finance \& Credit Reporting & 3 people \\
\hline Total & 37 people \\
\hline
\end{tabular}

While the sampling technique used is saturation sampling. Another word for saturated surveys is the census that surveys population representation. For this reason, samples taken from the population totaled 37 people, all of which were saturated.

\subsection{Method of collecting data}

1. Field Research, this technique is done by direct observation of the institution that is the object to get primary data (data taken directly from the company). This primary data was obtained through observation and interview.

2. Literature Research, this technique supports the obtaining of library data by researching, studying, and examining literature relating to the problem being examined containing books, journals, and papers relating to research.

3. Internet research, in this study, the authors tried to collect data obtained from sites related to various kinds of information needed in research.

\subsection{Research Instruments (Variable Operationalization)}

There are two variables consisting of one independent variable and one dependent variable. These variables are Risk Management (X) and Credit Lending (Y).

\subsection{Data analysis technique}

1. Validity Test and Reliability Test

Validity, the level of accuracy between the data that occurs in the object of research with the strength that can be reported by researchers. Valid data are the same data between data reported by researchers and what actually happens to the research object (Sugiyono, 2017). Reliability, a tool to measure the questionnaire, which is an indicator of a variable or constructs. A questionnaire is said to be reliable or reliable if a person's answer to a statement is consistent or stable from time to time (Imam, 2011). In this study the validity of items was measured by comparing the value of $r$ arithmetic and $r$ tables, that is $\mathrm{r}$ arithmetic obtained from the results in the column correlated item-total correlation. If the value of $r$ count $>r$ table, then the item or question or indicator is declared valid (Imam, 2011).

\section{Classic assumption test}

It was performed to decide whether the proven regression model could be used as a strong predictor. The regression model is assumed to be a strong model if the model fulfills the standard free statistical assumptions. The classical assumption test used in this study consists of the normality and heteroscedasticity test. Multicollinearity tests were not carried out because the regression model used was a simple linear regression rather than multiple linear regression. While the autocorrelation test was not carried out because the data used were not in the form of time series, because autocorrelation often occurs in samples with time series (Imam, 2016). 


\section{Data analysis}

Data analysis is a way to manage the collected data so that it can then provide interpretation. According to Nuryaman \& Veronica (2015) the purpose of data analysis and interpretation is to answer research problems that have been formulated in previous research steps, so that the results of data analysis and interpretation, can be used as a basis in making conclusions and recommendations for readers, particularly decision-makers in business. Data were analyzed using interval scale data measurement techniques obtained from questionnaires. The analysis methods used in this study were simple linear regression analysis, correlation coefficient analysis, determination coefficient and hypothesis test (t-test).

\section{Results and discussions}

In this section, the author described the survey results that had been obtained. This study aimed to determine whether Risk Management affects the Provision of Credit at PT. BPR Supra Antapersada of Bandung City. The independent variable in this study was Risk Management, while the dependent variable in this study was the Provision of Credit. The research was conducted in 2020. The subject in this study was PT. BPR Antapersada from the City of Bandung. A description profile of the respondents was developed to clarify the context of the respondents used in this study as samples. The profile of the respondent was described by sex, age, education level, and length of work. The details gathered by the author on the respondents' profile were:

1. Of the 37 people who became respondents in this study, it was seen that there were more male respondents than women at $65 \%$, while women at $35 \%$. The table shows that more than half of the employees of BPR Supra Antapersada are Male. This indicates that work at PT. BPR Supra Antapersada requires high mobility so it is more suitable for men.

2. Of the 37 people who became respondents in this study, it was seen that most respondents aged $25-50$ years were 18 people (49\%), and aged under 25 were 13 people (35\%) while respondents with the least age were> 50 years, namely 6 people $(16 \%)$. From this information, it can be seen that the majority of respondents aged between 25-50 years. The age is a productive age that has high morale.

3. Of the 37 people who became respondents in this study, it was seen that the most respondents with S1 / D4 education status were 15 people (40\%), D1 / D2 / D3 were 10 people (27\%), high school education was 9 people (24\%), while the respondents with the least education status were > S2, which was 9\%. From this information, it can be concluded that more respondents are educated S1 / D4. This is because S1 / D4 education is considered to be adequate in doing work.

\subsection{Test results validity and reliability tests}

1.Validity Test Results

The validity test is carried out to find out whether the questionnaire can measure the variables that already exist. Validity testing is done by correlating the respondent's answer score from each response. The value of $r$ arithmetic compared with $r$ table, approved $r$ arithmetic $>r$ table it can be concluded that the data is valid. Based on the recapitulation of the results of the instrument validity testing above, it is known that all statements submitted in measuring each statement have a value of $r$ count> r-table 0.361 which show that all statements submitted have performed the measurement function, in other words it has been declared valid. And from the results of reliability testing, the reliability coefficient value obtained is $0.956>0.600$ which show that the measuring instrument regarding risk management is reliable. Based on the recapitulation of the results of the instrument validity testing above, it is known that all statements submitted in measuring each statement have a value of r-count> r-table 0.361 which show that all statements submitted have performed the measurement function, in other words it has been declared valid. And from the results of reliability testing, the reliability coefficient value obtained is $0.973>0.600$, which shows that the measurement tool on credit has demonstrated its reliability.

\section{Reliability Test Results}

The stability and consistency of respondents in answering matters related to statements variable regulated in the questionnaire need to be measured. Reliability tests can be carried out together with 
all items for more than one variable. The reliability test results for the risk management variables are as follows:

a. Reliability of Risk Management Variables

Table 4

Risk Management Variables Result

Reliability Statistics

\begin{tabular}{|c|c|c|}
\hline $\begin{array}{c}\text { Cronbach's } \\
\text { Alpha }\end{array}$ & $\begin{array}{c}\text { Cronbach's } \\
\text { Alpha Based } \\
\text { on } \\
\text { Standardized } \\
\text { Items } \\
\end{array}$ & $\mathrm{N}$ of Items \\
\hline .956 & 960 & 17 \\
\hline
\end{tabular}

Source: SPSS Output Results

From the table above the reliability value of the risk management variable is 0.956 , because $r$ is $>0.60$, then the risk management variable has fulfilled the reliable criteria. While the results of testing the reliability of credit extension variables are as follows:

b. Reliability of Credit Lending Variables

Table 5

Credit Lending Variables Result

Reliability Statistics

\begin{tabular}{|c|c|r|}
\hline $\begin{array}{c}\text { Cronbach's } \\
\text { Alpha }\end{array}$ & $\begin{array}{c}\text { Cronbach's } \\
\text { Alpha Based } \\
\text { on } \\
\text { Standardized } \\
\text { Items }\end{array}$ & N of Items \\
\hline .973 & .975 & 17 \\
\hline
\end{tabular}

Source: SPSS Output Results

From the table above the reliability value of the credit variable is 0.973 , because $r$ is $>0.60$, then the credit variable has fulfilled the reliable criteria.

\subsection{The result of classical assumption test}

Before testing hypotheses using simple linear regression, there are several classic assumption tests that must be met so that the regression conclusions are not biased namely the normality test, and the heteroscedasticity test.

\section{Normality Test}

This aims to check whether the independent and dependent variables have normal distribution in the regression model or not. A good regression model is a model with a normal distribution or a near normal distribution. To detect whether there is a violation of the normality assumption can be seen using the Kolmogorov-Smirnov (K-S) method with the following conditions:

The population distribution is normal when the likelihood reaches 0.05 , and when the likelihood is less than 0.05 , the population distribution is not normal. 
Table 6.

\section{Normality One-Sample Kolmogrov-Smirnov (K-S) Result}

\begin{tabular}{|c|c|c|c|}
\hline \multicolumn{4}{|c|}{ One-Sanqle Kolmogorov-Smirnov Test } \\
\hline & & $\begin{array}{c}\text { Manajemen } \\
\text { Resiko }\end{array}$ & $\begin{array}{c}\text { Pemberian } \\
\text { Kredit }\end{array}$ \\
\hline $\mathrm{N}$ & & 37 & 37 \\
\hline Normal Parameters ${ }^{a, b}$ & Mean & 49.5568 & 46.7324 \\
\hline & Std. Deviation & 11.80303 & 13.26045 \\
\hline Most Extreme Differences & Absolute & .164 & .114 \\
\hline & Positive & .070 & .113 \\
\hline & Negative & -.164 & -.114 \\
\hline Kolmogorov-Smimov Z & & .998 & .696 \\
\hline Asymp. Sig. (2-tailed) & & .272 & .719 \\
\hline
\end{tabular}

\section{Source: Modified Output Of IBM SPSS 21}

Based on the results of normality test data presented in table 2, it appears that the probability value (sig) of each variable $>0.05$ which indicates that the data used has a normal distribution. In other words, the assumption of data normality is fulfilled.

\subsection{Heteroscedasticity test}

It aims to test whether residues from one observation to another occur in the regression variant. If the observations are identical, they are called homoscedasticity and if not they are called heteroscedasticity. To detect whether or not there is a violation of heteroscedasticity, it can be seen by using a scatter plot test with the following conditions:

If certain patterns such as dots form ordinary patterns (wavy, widened, then narrowed), then heteroscedasticity has occurred. And if there are no clear patterns and points spread above and below zero on the $\mathrm{Y}$ axis then heteroscedasticity does not occur.

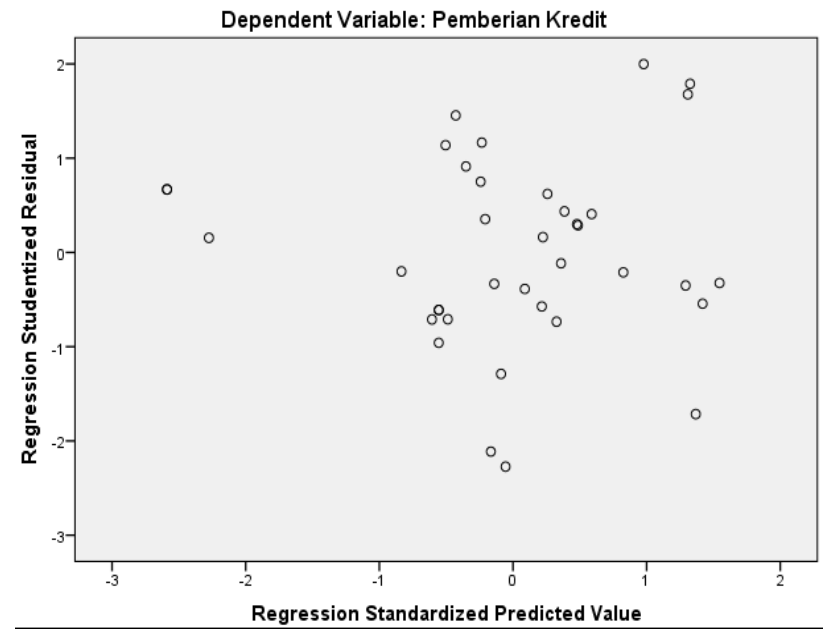

Figure 3: Heteroscedasticity Testing Results

Based on figure 3 shows the results of heteroscedasticity testing using the scatter graph method. From this figure it can be seen that the points obtained form irregular random patterns and spread above and below zero (0) on the $\mathrm{Y}$ axis, so that in the regression model to be formed there is no violation of heteroscedasticity, with the word residual variance becoming homoscedasticity.

\subsection{Verification analysis}

As explained in the previous section, the main purpose of this study was to determine the effect of risk management on credit extension at BPR Supra Anterpersada. To answer these problems, a simple 
linear regression analysis consisting of a simple linear regression equation, correlation coefficient, determination coefficient, and hypothesis testing by first testing the classic assumptions.

\section{Simple Linear Regression Equations}

The simple linear is as follows:

$\mathrm{Y}=\mathrm{a}+\beta \mathrm{X}$

Where:

$\mathrm{Y}=$ estimated value for granting credit

$\mathrm{a}=$ constant

$\mathrm{X}=$ risk management

By using SPSS software, the results of simple linear regression analysis are obtained as follows:

Table 7.

\section{Verification Analysis}

C'oefficients $^{3}$

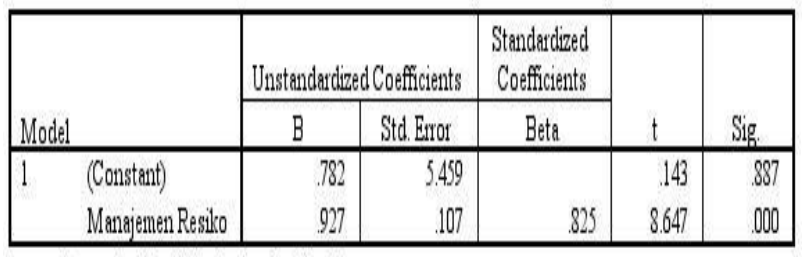

8. Dependent Varialde: Pentberizn Kredit

\section{Source: Modified Output Of IBM SPSS 21}

Based on table 3 obtained a simple linear regression equation as follows:

$\mathrm{Y}=0.782+0.927 \mathrm{X}$

From the results of a simple regression equation as follows:

a. The constant 0.782 shows that when risk management is zero (0) and there is no change, the credit is estimated to be worth 0.782 times.

b. Variable X, namely risk management, has a regression coefficient of 0.927 indicating that when risk management has increased, it is predicted to increase lending as much as 0.927 times.

\subsection{Correlation analysis}

Correlation analysis aims to measure the strength of linear associations (relationships) between two variables. Correlation does not distinguish between dependent variables and independent variables. The strength of the relationship between the independent variable (risk management) and the dependent variable (lending procedure) was measured using Pearson's Product Moment Correlation (PPM) analysis technique. The results of the correlation analysis between the independent variable and the dependent variable can be seen in the following table:

\section{Table 8.Correlation Analysis Result}




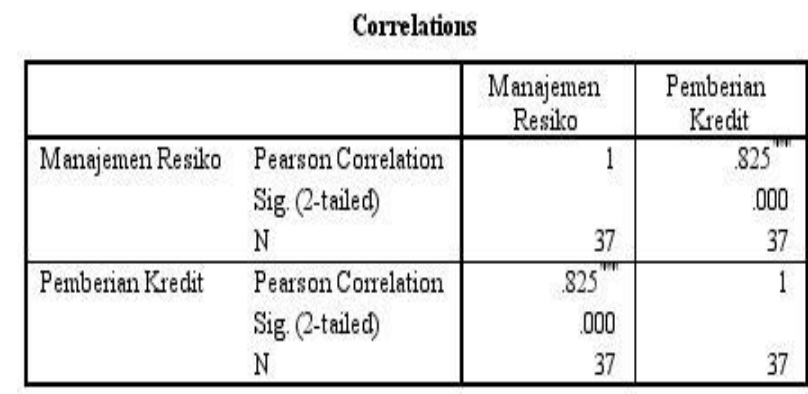

**. Correlation is signific ant at the 0.01 level (2-tailed).

\section{Source: Modified Output Of IBM SPSS 21}

Based on table 3, it is known that the correlation value obtained between risk management and credit provision is 0.825 . The correlation value is positive, which indicates that the relationship between the two is unidirectional. Where the better risk management, will increase lending. Based on the interpretation of the correlation coefficient, the correlation value of 0.825 belongs to the category of a very strong relationship, which is in the class interval of $0.800-1,000$.

\subsection{Coefficient of determination $\left(R^{2}\right)$}

$\left(\mathrm{R}^{2}\right)$ basically aims to measure the extent of the model's ability to explain variations in the dependent variable. By using SPSS, the coefficient of determination can be seen as follows:

Table 9.Coefficient of Deterination

\begin{tabular}{|c|c|c|c|c|}
\hline \multicolumn{5}{|c|}{ Model Sumunary $y^{\mathbf{b}}$} \\
\hline Model & $\mathrm{R}$ & RSquare & $\begin{array}{l}\text { Adjusted R } \\
\text { Square }\end{array}$ & $\begin{array}{l}\text { Std. Error of } \\
\text { the Estimate }\end{array}$ \\
\hline 1 & $.825^{8}$ & .681 & .672 & 7.59410 \\
\hline
\end{tabular}

\section{Source: Modified Output Of IBM SPSS 21}

Based on the table 4, information is obtained that the correlation coefficient or (R) obtained is 0.825 . Thus the coefficient of determination can be calculated as follows:

$$
\begin{aligned}
\mathrm{Kd} & =(\mathrm{r})^{\wedge} 2 \times 100 \% \\
& =(0.825)^{\wedge} 2 \times 100 \% \\
& =68.1 \%
\end{aligned}
$$

Based on the above calculation results, it appears that the coefficient of determination obtained by $68.1 \%$. This shows that risk management contributes to the lending of $68.1 \%$, while the remaining $31.9 \%$ is contributed by other variables not examined.

\subsection{Hypothesis testing (- test)}

To prove whether risk management has a significant effect on lending, hypothesis testing is carried out with the following hypothesis formulation:

$\mathrm{H} 0: \beta=0$, meaning that risk management has no significant effect on lending at BPR Supra Anterpersada.

$\mathrm{H} 1: \beta \neq 0$, meaning that risk management has a significant effect on lending at BPR Supra Anterpersada.

Significance level $(\alpha)$ : 0.05 
Test criteria: reject $\mathrm{H} 0$ if the value of $\mathrm{t}$-count> $\mathrm{t}$-table, $\mathrm{H} 1 \mathrm{accept}$

The $\mathrm{t}$ test statistic value can be known from the following output table:

Table 10.Hypothesis Testing ( $t$ test)

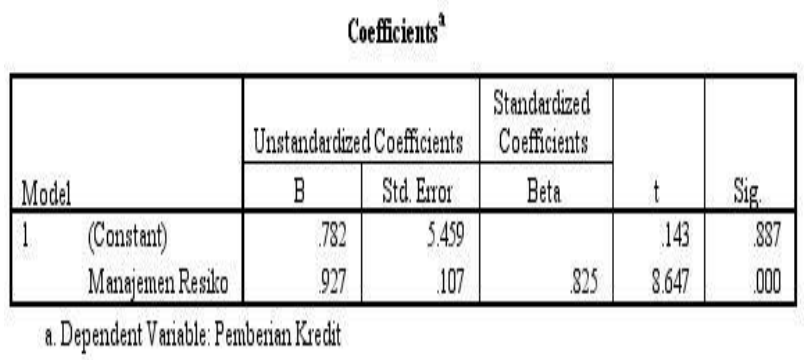

\section{Source: Modified Output Of IBM SPSS 21}

Based on table 5, it is known that the calculated value of $\mathrm{t}$ is 8.647 . This value will be compared with the $\mathrm{t}$-table value in the $\mathrm{t}$ distribution table. With $\alpha=0.05, \mathrm{df}=\mathrm{n}-\mathrm{k}-1=37-1-1=35$, the $\mathrm{t}$-table value for two-party testing is obtained (-2.030 and 2.030). From the values above, it can be seen that the calculated t-value obtained is 8.647 , which is outside the t-table values $(-2.030$ and 2.030$)$. In accordance with the hypothesis testing criteria that $\mathrm{H} 0$ is rejected and $\mathrm{H} 1$ is accepted, it means that risk management has a significant effect on lending at BPR Supra Anterpersada.

\subsection{Discussion result}

Based on the results of research on credit management planning for the implementation of credit were explained in the results of the discussion as below:

a. Effect of Risk Management on PT. BPR Supra Antapersada

Based on the recapitulation of the respondents' responses above, it is known that the overall average value obtained by the risk management variable is 3.75 and is categorized as good. So it can be concluded that risk management at BPR Supra Antapersada is considered to be adequate. The COSO is as follows: Based on the processing of questionnaire data about risk management variables, each is related to each indicator related to the role of management to credit suppliers. This can be seen from the score of respondents' answers on the questionnaire about risk management.

The most important risk management indicators in the best credit category, Goal Setting in the good category, Internal Environment in the good category, Monitoring in the good category, Risk Assessment in the good category, Identification of the Goals in the good category, Risk Response in the category good, information and communication are in the good category and those in the Control Activity indicator while still in the good category.

1. The environmental control indicators in the company already have a good average value obtained by the internal environment dimension of 3.88 and are categorized as good.

2. Indicators of goal setting in the company the results of the study note that the average value obtained amounted to 4.19 and categorized well. So it can be concluded that the company has determined every operational, reporting and compliance activity must be in accordance with company rules.

3. Indicators of identification of objectives in the company the results of the study note that the average value obtained was 3.73 and categorized as good. So it can be concluded that each credit transaction is classified according to the level of risk.

4. The risk assessment indicators in the company already have an average value obtained by the dimensions of the internal environment of 3.78 and are categorized as good.

5. Indicators of risk response in the company are already good and have an average value obtained by the dimensions of the internal environment of 3.65 and are categorized as good.

6 . The indicator of control activities in the company is good and has an average value obtained by the internal environment dimension of 3.50 and is categorized as good. 
7. Indicators of information and communication in the company the results of the study note that the average value obtained was 3.57 and categorized well. So it can be concluded that each credit transaction is classified according to the level of risk.

8. Monitoring indicators in the company, the results of the study note that the average value obtained was 3.86 and categorized as good. So it can be concluded that each credit transaction is classified according to the level of risk.

The purpose of the results of this study aims to determine the effect of risk management at PT. BPR Supra Antapersada. Risk management is the method used to coordinate a company to achieve company goals through the procedures and organizational structure of the company. This is done to improve the effectiveness and efficiency of bank performance in channeling credit to prospective debtors and minimize the arrears of credit payments and even uncollectible loans, causing the risk of bad loans. Therefore, banks must be able to detect the risk of bad loans early so as not to cause losses from the amount of credit arrears by customers with risk management.

The results of this study are in line with the results of previous studies conducted by (Mustikawati et. al., 2013), (Erwindi, 2016), and (Pratiwi, 2016). The results of their researches indicate that risk management influences the provision of credit. Research reinforces the theory put forward by (Idroes, 2011) that risk management is defined as a methodological and systematic way of identifying, measuring, determining attitudes, setting solutions, and monitoring and reporting risks that occur in every activity or process.

b. Providing Credit to PT. BPR Supra Antapersada

In processing questionnaire data regarding the lending variable, there are indicators of assessments from good to quite good which include:

1. Character analysis is included in the quite good category. based on the results of the study note that the average value obtained is 3.40 and is categorized quite well. So it can be concluded that the Bank always pays attention to the character of the prospective debtor quite well.

2. Capacity analysis is included in both categories. According to the results of the study note that the average value obtained is 3.58 and categorized well. So it can be concluded that banks always pay attention to the ability of prospective borrowers long before the loan.

3. Capital analysis in the good category. From the results of the study note that the average value obtained was 3.55 and categorized well. So it can be concluded that the bank always pays attention to the capital situation of the prospective debtor well.

4. Analysis of Economic Conditions included in both categories. The highest indicator loan variable is Economic Condition. From the results of the study note that the average value obtained is 3.66 and categorized well. So it can be concluded that banks always pay attention to the economic conditions of prospective borrowers before lending.

5. Collateral analysis falls into either category. From the results of the study note that the average value obtained was 3.57 and categorized well. So it can be concluded that the bank requires providing guarantees to prospective borrowers.

Effect of Risk Management on Credit Provision at PT. BPR Supra Antapersada Based on the results of research on the effect of risk management by considering the five principles of lending according to Kasmir (2014), all responses from respondents are included in the quite good and good category. This can be said of granting credit at PT. BPR Supra Antapersada is already in the good category or the bank has implemented an analysis or is careful in providing loans to prospective debtors. Effect of Risk Management on Credit Provision at PT. BPR Supra Antapersada

c. Effect of Risk Management on Credit Provision at PT. BPR Supra Antapersada

The purpose of this study aims to determine the effect of risk management on lending, in this study the questionnaire was divided into two variables, namely risk management and lending. Risk management is a method used to coordinate companies to achieve company goals which include the organizational structure of the company, procedures established by the company, and healthy work practices. This is done to improve the effectiveness and efficiency of bank performance in lending and minimize arrears in credit payments. Banks must be able to detect the risk of bad credit early so as not to incur losses from the amount of credit arrears by the customer. 
Based on the hypothesis testing that has been done by the author, the results show that risk management influences the provision of credit to BPR Supra Antapersada Bank. This means that the hypothesis that the authors propose that risk management influences lending can be accepted. The study is in line with previous studies conducted by Mustikawati et. al, (2013). The results of these studies indicate that PT. Bank Tabungan Pensiunan Nasional Kediri Branch has implemented well the Supervision of the Board of Commissioners and Directors of the Board of Commissioners and Directors, the adequacy of the process of identification, measurement and monitoring of credit risk, and risk control. Research reinforces the theory put forward by Idroes, (2011) that risk management is an attempt to find out, analyze and control risk in every company activity with the aim of obtaining higher effectiveness and efficiency. With the implementation of good risk management, lending can be carried out effectively. So the better the risk management is applied, the better the credit is given.

\section{Conclusion}

Risk management at PT. BPR Supra Antapersada in Bandung City is adequate. Overall, each component of risk management starting from the internal environment, goal setting, problem identification, risk assessment, risk response, control activities, information and communication, and monitoring fall into the good category. Providing credit to PT. BPR Supra Antapersada based on the principles of lending, is sufficient. Every component in the principles of credit has been applied to credit. Risk management influences crediting based on the principles of crediting based on the results of the statistical test that the calculated $t$ value is greater than the $t$ table value. The coefficient that produces a positive value indicates a positive relationship between risk management and lending, where the higher the risk management, the better the lending.

\section{Limitation and study forward \\ Limitations}

Research limitations obtained during the study are as follows :

1. This research was only focused on risk management factors on credit landing.

2. The subject of research was only fixated on PT. BPR Supra Antapersada Bandung.

3. This research was only carried out from February 2020 to May 2020.

\section{Study forward}

Based on the limitations of the study, the authors provide several suggestions for further researchers as follows:

1. Future researchers will not only focus on the factors in this study, namely risk management, but can add to other factors that may affect the loan as well as the auditor's experience, auditor expertise, skepticism, and other factors.

2. So that the results of this study can be widely used, it is expected that further research subjects will not only focus on PT. BPR Supra Antapersada Bandung, but can use other research subjects.

3. The research time should be longer so that the data obtained is really maximum and better

\section{Acknowledgement}

During the research, the research is free of cost from PT. BPR Supra Antapersada and Widyatama University. Researchers only pay accommodation costs when observing and incur costs to publish this research in order to become articles. Researchers can succeed in conducting this research were several people and agencies who had helped researchers both financially and non-financially in completing this research, as follows:

1. Families, especially parents who have provided financial support and encouragement, brothers and sisters who have provided support and encouragement so that researchers can complete this research properly.

2. Widyatama University as a campus where researchers study, without exception, lecturers who have helped and supported researchers in the success of the research.

3. People's Credit Bank, PT. Supra Antapersada from Bandung City has given permission for researchers to conduct research and internships, including employees who have provided lessons and assistance while conducting research. 
4. Researching friends who have provided assistance and enthusiasm for researchers in completing this research.

5. Especially God, who has given the authors age, health, breath, and opportunities so this research can be completed properly and on time.

\section{References}

Bura, E., \& Kadero, S. (2013). Risk management-based internal audit for auditor to improve the performance of internal audit unit of PT.Timah (Persero) TBK. The Indonesian Journal of Business Administration, 2, 1962-1968.

Gischa, Serafica. (2020). Bank umum dan BPR: Perbedaan dan Persamaannya. https://www.kompas.com/skola/read/2020/01/29/180000269/bank-umum-dan-bpr-perbedaan-dan-persamaannya?page=all

Idroes, F. N. (2011). Manajemen risiko perbankan. PT. Raja Grafindo Persada.

Imam, G. (2011). Aplikasi analisis dengan program SPSS. Badan Penerbit Universitas Diponegoro.

Imam, G. (2016). Aplikasi analisis multivariate dengan program IBM SPSS 23 (Edisi 8). Badan Penerbit Universitas Diponegoro.

Irfandhi, K. (2016). Risk management in information technology project: an empirical study. ComTech, 7, 191-199. https://media.neliti.com/media/publications/166132-EN-riskmanagement-in-information-technolog.pdf

Kasmir. (2014). Bank dan lembaga keuangan lainnya. PT. Raja Grafindo Persada.

Kasmir. (2015). Dasar-dasar perbankan. PT. Raja Grafindo Persada.

Mustikawati, N., Topowijono, \& Dwiatmanto. (2013). Penerapan manajemen risiko untuk meminimalisir risiko kredit macet. Jurnal Administrasi Bisnis, 4(1), 1-7.

Nuryaman., \& Veronica. (2015). Metedologi Penelitian Akuntansi dan Bisnis. Ghalia Indonesia.

Otoritas Jasa Keuangan. (2015). Penerapan manajemen risiko bagi Bank Perkreditan Rakyat.

Pratiwi, Y. W. (2016). Analisis manajemen risiko kredit untuk meminimalisir kredit modal kerja bermasalah (Studi pada PT. Bank Rakyat Indonesia (Persero), Tbk Cabang Ponorogo). Jurnal Administrasi Bisnis, 38

Sari, L. K. (2012). Penerapan manajemen risiko pada perbankan di Indonesia. Jurnal Unesa, 1(1) 121.

Sugiyanto, S., \& Rahayu, A. A. (2018). The implementation of risk management and its effect on good cooperative governance and success. Journal of Indonesian Economy and Business, Volume 33, $243-256$.

Sugiyono. (2017). Metode penelitian kuantitatif, kualitatif, dan R\&D. Alfabeta.

Suhardi. (2006). Risiko dalam pemberian kredit perbankan.

Suharto, E. S. (2015). Risiko dalam perjanjian kredit perbankan menurut peraturan bank indonesia nomor 5/8/PBI/2003 tentang penerapan manajamen risiko bagi bank umum. Privat Law, 7 January-June 2015.

Tursoy and Turgut. (2018). Risk management process in banking industry. Munich Personal RePEc Archive (MPRA), 86427(02 May 2018 14:20), 1-36.

Wareza, M. (2019). Duh! Pefindo Biro Kredit Sebut NPL BPR Capai 7\%. Cnbc Indonesia, Cnbcindonesia.com.

Wikipedia. (2019). Kredit atau keuangan. Id.Wikipedia.Org.

Wikipedia. (2020). Populasi (Disambiguasi).

https://id.wikipedia.org/wiki/Populasi_(disambiguasi)\#: :text=Populasi adalah kumpulan individu sejenis,pada waktu yang tertentu pula.\&text=Dalam biologi $\% 2 \mathrm{C}$ populasi adalah sekumpulan,tempat dan waktu yang sama. 